\title{
KRYZYS DOJRZEWANIA JAKO PROBLEM PSYCHOLOGICZNY
}

Psychologiczne aspekty kryzysu dojrzewania stanowią zagadnienie niezwykle ciekawe. Rozwiązanie niektórych problemów nastręcza jednak wciąż jeszcze wiele trudności. Istnieje bowiem szereg spornych kwestii terminologicznych, merytorycznych a także fałszywych poglądów, narosłych ad wielu lat wokół okresu dojrzewania młodizieży.

\section{KOGO NAZYWAMY DOJRZEWAJĄCYM?}

Najpierw należy zdać sobie sprawę z różnicy między pojęciem ,dorosłość,, i „,dojrzałość”. Człowiek dorosły to taki, który jest zdolny do samodzielnego uczestnictwa w życiu społecznym. A zatem, „dorosłość" jest kategorią społeczną. Człowiek „do'jrzewa” jako organizm psychofizyczny przez kilkanaście lat swego życia, co nie znaczy, że już jest dorosły do życia "w społeczeństwie. „Dojrzałość” jest więc raczej kategorią biologiczną. Następnie, wypada się zastanowić nad kwestią granicy wieku osoby dojrzewającej. Istnieją w tej kwestii dwa' kryteria:

1) Biologiczne (zmiany wzrostowe; zmiany dojrzewania płciowego),

2) Psychologiczne (świadomość własnych zmian pokwitaniowych oraz zmian odnośnie ksżtałtowania się poczucia tożsamości).

Pierwsze krytérium odwołuje się do objałów fizjologicznych (u Dz. pierwiza menstruacja; u Ch. pierwsza zmaza nocna). Według E. B. Hurlock należało by przyjąc w tym względzie 13 r.ż, u Dz., a 14 r.ż. u Ch. ${ }^{1}$ Skądinąd wiemy, że dziewczęta dojrzewają wcześniej, niż chłopcy. Przyjmuje się, że dziewczęta wy'przedzałą chłopców w idojrzewaniu o dwa lata. Dla zakończenia okresu dojrzewania autorzy przyjmują (np.

1 E. B. Hurlock, Adolescent Development, 3rd edition, New York Mc Graw-Hill 1967 , s. 2.

Uwaga: Autorka aprobując znaczenie intensywnych zmian wzrostowych w okresie przedpokwitaniowym (podobnie: J. M. Josselyn, L. J. Stone and J. Church 1968), oddziela początek adolescencji od początku dojrzewania seksualnego, który według niej przypada u Dz. w 13 r.że, u Ch. w 14 r.ż. 
E. Jones ${ }^{2}$, D. J. Holmes $\left.{ }^{3}\right)-18$ r. ż., natomiast E. Hurlock przesuwa tę gránicę do 21 r. ż. ${ }^{4}$. Wynikało by z tego, że niektór'zy autorzy wprowadzają jeszcze trzecie kryterium dla określenia zakończenia dojrzewania, a miahowicie wiek dojrzałości umysłowej (matura). Ukończenie szkoły średniej, podobnie jak początek dojrzewania płciowego są terminami płynnymi. Różnice balansują tutaj od jednego do paru lat.

Toteż, wśród współczeshych autorów zaczyna ustalać się pogląd, że lepiej było by granice wieku dojrzewania ,ujmować, nie w termínach biologicznych, ale w terminach procesów psychologicznych. I tak, Irwing B. Weiner sądzi, że wiek dojrzewania (dorastania) rozpoczyna'się od wczesnych reakcji psychicznych dziecka na swoje fizyczne zmiany pokwitaniowe (wzrost, objawy dojrzewania płciowego) i rozciąga się i dopier@ wốwczas końc zy się, gdy dochodzi do pełnego poczucia ukształtowania się tożsamości ${ }^{5}$. Najczęściej zdarzenia te wg w/m autora występują pomiędzy 11 a 21 r.ż. ${ }^{6}$

\section{KIERUNKI DOJRZEWANIA PSYCHICZNEGO}

Dojrzewaniem psychicznym nazywamy proces osiągania stopniowego rozwoju właściwości psychicznych organizmu aż do poziomu, umożliwiającego wykonywanie określonych czynności. Jest to zatem, ogół procesów i zmian, stanowiących przejście od dziecinstwa do dojrzałości psychicznej (zmia'na systemu wartości, motywów, życia uczuciowego). Zanim przy'patrzymy się szeregu uwarunkowaniom, którym podlega dojrzewanie w okresie dorastania, spróbujmy już obecnie nakreślić charakterystyczne kierunki rozwoju psychicznego, kitóre są przedmiotem badań psychologii rozwojowej. Można by je przedstawić następująco:

- od funkcji niezróżnicowanych do funkcji zróżnicowanych,

- od myślenia konkretnego do myślenia abstrakcyjnego,

- od uwagi mimowolnej do uwagi dowolnej,

- od analizy do syntezy (kilkakrotnie, na coraz wyższym poziomie),

— od zabawy do poważnej pracy,

- od egocentryzmu do altruizmu,

— od reakcji spo'ntanicznych do refleksyjných,

- od naiwności do krytycyzmu,

2 E. Jones, Some problems of adolescence. „British Journal of Psychology”, 13: $41-47,1922$. s. 26 .

3 D. J. Holmes, The Adolescent in Psychoterapy. Boston, Little Brown, 1964,

4 E. Hurlock, dz. cyt. s. 2.

5 Irwing B. Weiner, Zaburzenia psychiczne wieku dorastania, PWN Warszawa 1977, s. 28.

6 Tamże. 
- od percepcji bardziej emocjonalnej do bardziej inttelektualnej,

- od sensualizacji do spiritualizacji (w dziedzinie religijności),

- cd uczuć prostych do złożonych (emocjonal'ność),

— cd reakcji nieodpowiedzialnej do odpowiedzialnej (wola),

— od postawy bardziej ekstrawertywnej do bardziej intrawertywńej,

- od idealizmu do realizmu,

- od działania zależnego do działania niezależnego,

- od akty'wności egocentrycznej do aktywności społecznej,

- od wiedzy i informacji do mądrości życiowej,

- od zbytnielj pewności siebie do pokdrnej skromności,

— od teorii do praktyki (przeobrażenie wiedzy w czyn),

- od rozwijania talentu do tworzenia dojrzałych dzieł itp.

Są to tyllko niektóre, szczególnie ważne i najbardziej zauważalne linie rozwoju psychicznego od dzieciństwa do lat dojrzewania psychicznego. Przy tym, procesy te nie kończą się w sposób ostateczny wraz z osiągnięciem dojrzałej samoświadomośdi. Trwają one aż do starości. Ale ich intensyfikacja jest dla ok'resu dojłrzewania szczególnie znamienna. W późniejszych latach róść będzie przede wszystkim pozytywna przeróbika cech osobowościowych w wyniku zdobywanego doświadczenia (obok warunków biologicznych, środowiskowych i uczenia się) .w zakresie pożnawczo-uczuciowo-dążeniowym.

\section{UWARUNKOWANIA PROCESOW DOJRZEWANIA}

„Człowiek stworzony jest do zmieniania się i musi się zmieniać”. Te słowa Paul Chaucharda mają szczególną wymowę w okresie dojrzewania. Proces dojrzewania nie jest jednak czymś samorzutnym i autonomicznym. Dokonuje się on pośród wielu uwar'unkowan. Powstaje problem, czym jest zdeterminowana adiolescencja? Czy głównie biogenetycznie, czy raczej społecznie i kulturowo? Poglądy a'utorów są różne.

Jed'na grupa uczonych (G. S. Hall, Z. Freud, E. Jones i ín.), idąc po linii J. J. Rousseau ", reprezentują stanowisko, według ktớrego rozwój człowieka odbywa się zgodnie z pewnymi z góry genetycznie uwarunkowanymi zmianami, na które środowisko bardzo rzadko oddziałuje. Dokonujące się $\mathrm{w}$ psychice (i w organizmie) zmiany byłyby zatem biolcgicznie uniwersalne $\mathrm{i} w$ pewien sposób spontaniczne i niezależne od uwarunkowań, w jakich jednostka ludzka przebywa i jakim jest poddana.

7 J. J. Rousseau (1762), Emile. Translates by B. Foxley, London 1911, s. 7 n. 16 - Analecta Cracoviensia 
Druga - grupa - w myśl stanowiska Johna Lock'a o człowieku jako tabula rasa ${ }^{8}$ - twierdzi, że czynniki biogenetyczne w człowieku stanowią wprawdzie pewne predyspozycje rozwojowe, ale najważniejszymi determinantami jego możliwości rozwojowych są czynniki środowiskowe (podobnie sądzą: M. Mead ${ }^{9}$, E. Hurlock ${ }^{10}$, Stone i Church ${ }^{11}$ i in.). Autorzy tej grupy powołują się często na badania w zakresie antropologii kulturowej w latach 20 -tych i 30-tych, zwłaszcza na studium Margaret Mead (1928), przeprowadzonym wśród ludów wyspy Samoa (Polinezja), gdzie młodzież nie wyłkazywała charakterystycznych gdzieindziej niepokojów i konfliktów dorastania.

Co można o tym powiedzieć? Zarówno pierwsza, jak i druga opinia, wydaje się być opinią skrajną. Albowiem, ani wyłącznie czynniki biologiczne (neurologiczne), ani same tylko czynniki środowiskowe, nie tłumaczą reszty przemian rozwojowych w okresie dojrzewania. Toteż, R. L. Shapiro ${ }^{12}$ sądzi, że znaczny rozwój zdolności poznawczych we wczesnej adolescencji jest ,dostaltecznie analityıczny, a zarazem wystarczająco regularny i zgeneralizowany, aby potwierdzać przypuszczenie o autonomicznym rozwoju Ego, jako jednym z dojrzewających $w$ tej fazie elementów" ${ }^{13}$.

Wniosek byłby zatem następujący: Na przeobrażenia w okresie dojrzewania wpływają, zarówno czynniki k os ty tu c jo n a ln e, jak i d oświadczenie, czerpane z kontaktów z otoczeniem. Toteż, uwzględniając jedne i drugie czynniki, należało by się zastanowić raczej nad tym, w jakim stopniu czynniki te wpływają na procesy adolescencyjne.

Innym zagadnieniem, dotyczącym uwarunkowań procesów dojrzewania jest problem ciągłości dojrzewania, względnie jego charakteru „skokowego", organicznie nie związanego z okresem poprzednim, tj. z dzieciństwem. Innymi słowami, czy można mówić o łagodnym przejściu pomiędzy pierwszą a trzecią dekadą życia, czy też należało by przyjąć jakiś rodzaj ,skoku dojrzewania”. I znowu, autorzy są różnego zdania. Jedni, jak: G. S. Hall, E. Jones, F. Wittels, P. Rube twierdzą, że przemiany okresu dojrzewania są tak wielkie, iż można mówić o „,nowych narodzinach" ${ }^{14}$, czy 0 adolescencyjnej rekapitulacji, tj. powtórzenia się

8 J. Locke (1690), An Essay Concerning Human Understanding, New York: Dover 1959.

9 M. Mead, Coming of Age in Samoa, New York 1928.

10 E. Hurlock, American adolescents today - a new species „Adolescence”, 1: $7-21,1966$.

${ }_{11} \mathrm{~L}$. J. Stone and J. Church, Childhood and Adolescence, 2nd edition, New York, Random Housè 1968.

12 R. L. Shapiro, Adolescence and the psychology of the age, w: Psychiatry, 26: $77-87,1963$.

13 Tenże, s. 87.

14 Por. P. Rube, Is there a problem of adolescence? w: American Journal of Psychotherapy, 9: 503-509, 1955. 
faz rozwojowych, charakteryzujących dzieciństwo ${ }^{15}$, całkowite rozchwianie równowagi ${ }^{16}$, czy jak chce $\mathrm{P}$. Rube, różnica przemian tego okresu porównana być może do tej, jaka zachodzi między zapłodnieniem a porodem, a o jakiejkolwiek przejściowej fazie rozwojowej nie może być mowy ${ }^{17}$.

Inni autorzy, jak: L. S. Hollingworth, W. C. Bronson, P. M. Symonds, A. Jensen, L. B. Ames, T. Hertz, Ch. T. Baker - wyrażają opinię zdecydowanie odmienną od poglądu o, nowych narodzinach” w okresie dojrzewania. Twierdzą oni - na poddstawie badań longitudinalnych - że w okresie dojrzewania nie dochodzi do ukształtowania się całkowicie nowych cech charakterologicznych i osobowościowych.

L. S. Hollingworth sądzi, że przemiany rozwojowe w okresie dorastania mają charakter stopniowy i ciagły ${ }^{18}$. Podobnie W. C. Bronson, który mówi, że ,ciągłość rozwoju (osoby były badane w ciągu 30 lat) staje się oczywista, gdy bierze się pod uwagę charakterystyczne tendencje do określonego reagowania ${ }^{19}$. To samo podkreśla M. R. Hertz twierłząc, że zmiany osobowości w okresie dorastania mają charakter raczej ciągły, niż skokowy ${ }^{20}$.

Oczywiście, rozwój jest zawsze procesem a minore ad maius $\mathrm{z}$ tym, że pewne zachowanie będzie rzeczywiście kontynuacją zachowania z okresu dzieciństwa (trzeba jednak to zbadać i stwierdzić), inne zaś zachowanie będzie się 'wyraźnie różniło od zauważalnego w okresie latencji a także od zachowania w okresie późniejszej dorosłości. Zawsze jednak, będzie to wynik, rozwoju ciągłego, a nie skokowego. Szczególnie cenne są tu badania, prowadzone testem Rorschacha przez L. B. Ames'a osób w wieku oł 2 do 102 lat. Potwierdziły one wysoki stopień ciągłości procesów rozwojowych.

Następnie, powstaje pytanie, czy we współczesnym społeczeństwie zauważa się kontynuację adolescencji jako zbioru odrębnej kultury (wzgl. „,podkultury”), czy też zanik kontrastowości charakterystycznych cech dojrzewania pod wpływem współczesnego społeczeństwa.

Edgar Friedenberg w książce The Vanishing Adolescence ${ }^{21}$ jest zdania, że jednostka dorasta jedynie poprzez k o n likt ze s.połeczeń-

15 F. Wittels, The ego of the adolescent, In: K. R. Eissler (ed.). Searchlight on Deliquency. New York: International Universities Press, 1949, s. 256-262.

16 Tamże.

17 P. Rube, dz. cyt. s. 503 n.

18 L. S. Hollingworth, The Psychology of Adolscent, New York 1928, s. 1-17.

19 W. C. Bronson, Adult derivatives of emotional expressiveness and reactivity-control: Developmental continuities from, childhood to adulthood, w: Child Development, 38: 801-817, 1967.

${ }_{20}$ M. R. Hertz, The Rorschach in adolescence. In: A. I. Rabin and M. R. Haworth (eds.), Projective Techniques with Children New York: Grune and Stratton 1960 , s. $29-60$.

${ }_{21}$ E. Z. Friedenberg, The Vanishing Adolescent, Boston 1959, s. 307. 
s t w e m. Tymczasem, społeczeństwo dzisiejsze jest zdecydowanie wrogie wobec pozytywnych celów okresu dorastania: nie tolerujemy u młodych poczucia ich własnej tożsamości, namiętności zaangażowania; boimy się, że młodzi zdobędą większe, niż my doświadczenie, nie tolerujemy ich intymności emocjonalnej. E. Friedenberg twierdzi, że obecne społeczeństwo ,produkuje konformistów, młodzież jednorodnie zidentyfikowaną ze szkołą i innymi instytucjami”. Autor konkluduje, że „adolescencja, jako proces rozwojowy, staje się szczątkiem" ${ }^{22}$.

Kenneth Keniston w swej książce The Uncommited Alienated Youth in American Society sądzi, że pokolenie ludzi dorosłych zraża młodych do reprezentowanych przez siebie wartości. Młodzi uważają świat ludzi dorosłych jako mało atrakcyjny, że będą musieli poprzestać na czymś mniejszym, niż gdyby pozostali przy własnych nadziejach ${ }^{23}$.

Skutek jest taki, że według Friedenberga rośnie nam pokolenie młodych niekonfliktowe, a według Kenistona pokolenie borykające się $\mathrm{z}$ przeszkodami, ale bez zaangażowania i z uczuciem niezadowolenia. Autorzy ci mają $\mathrm{z}$ pewnością na uwadze warunki $\mathrm{w}$ swoich krajach, ale pewne oznaki unikania walki o wartości, lenistwa widać również u nas. Wobec braku zrozumienia przez dorosłych, młodzież niekiedy tworzy grupy rówieśnicze, w których obowiązuje swoisty język i normy, jako protest przeciw dorosłym egoistom czy nawet hipokrytom, żądającym od młodych tego, czego sami nie realizują ${ }^{24}$.

Stwierdzana niekiedy $\mathrm{u}$ młodych nieobliczalność $\mathrm{w}$ zachowaniu jest tylko tzw. reakcją upozorowaną. Prawdą jednak jest, że u młodzieży zauważa się zwiększoną podatność na załamania psychiczne ${ }^{25}$. Jeżeli zatem przyjąć, że w okresie dorastania wstrząs psychiczny miałby być nieuchronny, wówczas należało by młodych traktować $\mathrm{z}$ dużą tolerancją, cierpliwością i wyrozumiałością — tak zalecał już G. S. Hall. Jeśli natomiast, wstrząsy $\mathrm{w}$ okresie dorastania winno się przypisywać warunkom środowiskowym - co jest bardziej prawdopodobne - wówczas należało by stworzyć po prostu dogodniejsze dla rozwoju psychicznego warunki społeczne, a zwłaszcza wychowawcze. E. Hurlock reprezentuje to właśnie stanowisko, widząc szereg negatywnych zjawisk jako konsekwencję zbyt liberalnego wychowania. Pani Hurlock gani młodzież współczesną za: konformizm w stosunku do grupy; zainteresowanie symbolami statusu społecznego; nieodpowiedzialność; niechęć do pracy i antyintelektualne postawy; niedbałość o poprawne zachowanie, ubiór i dzi-

22 Tenże, s. 133.

${ }^{23} \mathrm{~K}$. Keniston, The Uncommited: Alienated Youth in American Society, New York 1965 , s. $396-398$.

24 Tenże, s. 394.

25 N. W. Ackerman, Adolescent problems: A symptom of family disorder, w: Family Process, 1: 202-213, 1962. 
wactwa; brak szacunku dla starszej generacji; krytycyzm i odrzucanie autorytetów; nieposzanowanie reguł i praw; nierealistyczny poziom aspiracji ${ }^{26}$. Pytanie powstaje, czy można tak mówić o młodzieży w ogóle? E. C. Kelley, na podstawie długoletniej praktyki nauczycielskiej w USA z młodzieżą unika generalizowania i mówi, że ,jest rzeczą oczywistą, że młodzież jako całość zachowuje się lepiej niż kiedykolwiek w przeszłości" ${ }^{27}$.

\section{GEOWWNE TRUDNOŚCI OKRESU DOJRZEWANIA}

\section{a) Konstytuowanie się samoświadomości}

Jednym $z$ najbardziej charakterystycznych objawów dojrzewania psychicznego jest nowe „odkrycie jaźni”, czyli własnego świata psychicznego, odrębnego, indywidualnego, autonomicznego, oryginalnego.

Istnieją w literaturze fachowej różne określenia Ego: Ja (jaźń), lch (selbst), Self (Proprium) wg Allporta, Moi (personnelle) - co oznacza: świadomość siebie, czyli samoświadomość. Ta ostatnia zwana jest również świadomością podmiotową, tj. skierowaną na sam reflektujący w danej chwili podmiot, którego uwaga skupiona jest na dokonujących się w nim samym aktach psychicznych. Inną odmianą świadomości jest świadomość przedmiotowa, tj. skierowana na świat zewnętrzny w stosunku do reflektującego podmiotu.

Owa świadomość siebie nie jest pojęciem treściowo pojedyńczym, ale złożonym (compositum), ponieważ człowiecze ,ja” tworzy szereg koncentrycznie konstytuujących je (tzn. „ja”) kręgów czy warstw: „ja”: cielesne, psychiczne, społeczne, kulturowo-twórcze, religijne ${ }^{28}$. Razem owe kręgi tworzą unum compositum naszego ,ja” osobowego, dającego nam świadomość, iż nasze akty do nas należą i są inne, niż te nie nasze, należące do drugich.

W poprzednim okresie rozwojowym uwaga dziecka skierowana była na przedmioty i sytuacje ekstrapersonalne, na tzw. „krąg rzeczy moich”. Mniej więcej od $12 / 13$ r. ż. następuje znamienny zwrot ku własnemu życiu psychicznemu. Ta fascynacja samym sobą, swoim wnętrzem, swymi dyspozycjami i procesami psychicznymi, krystalizuje się w latach dorastania i według niektórych w sposób stopniowy, według innych (np.

26 E. Hurlock, dz. cyt. s. $7-21$.

27 G. S. Hall, Adolescence: Its Psychology and Its Relations to Physiology, Anthropology, Sociology, Sex, Crime, Religion and Education, Vols. I, s. XIV-XVI.

${ }_{28}$ Por. E. Borowski, ks., Swiadomość siebie w przeżyciach młodzieży jako problem pedagogiczno-pastoralny, Lublin KUL, 1969, s. 351 (praca doktorska w maszynopisie). 
K. Dąbrowski) w formie nagłego oświecenia, stanowi „przejście od zauważania swych doznań, uczuć, myśli i działań, do stwierdzenia, że się . jest p o d mi ot em (p. m.), który doznaje, czuje, myśli, działa" ${ }^{29}$.

Punkt kulminacyjny krystalizowania się młodzieńczego „,ja” przypada według niektórych autorów na lata $16-18$ r. ż. ${ }^{30}$, lecz kończy się dopiero ok. 21 r. ż. (por. Irwing B. Weiner 1977, s. 28). Słusznie utrzymuje Ks. Wł. Prężyna o tym okresie, że ,jest to właśnie czas budzenia się pełnej świadomości, pełnej niezależności młodego człowieka w myśleniu i działaniu" ${ }^{31}$.

Jest to dla młodego bardzo trudny okres wypracowywania w sobie właściwej identyfikacji, odrębności, samodzielności, autokry.tycyzmu, odrywania się od dotychczasowych schematów, widzenia siebie, narzuconego przez autorytety: rodziców, nauczycieli, katechetów itp. Stąd, zauważane u młodych zamykanie się $\mathrm{w}$ sobie (uwewnętrznianie procesów psychicznych), krycie się $\mathrm{w}$ cień filarów kościelnych, trudność z uzewnętrznianiem swego życia religijnego (opór przy śpiewaniu, klękaniu), trudność w uczeniu się definicji katechizmowych, ponieważ uwaga ich skierowana jest na wielkie śyntezy, harmonizowanie szczegółów, myślenie horyzontalne, abstrakcyjne i zawsze krytyczne. Dużą pomocą w dokonywaniu się tych procesów jest powstająca w tym czasie w młodej psychice potrzeba autorefleksji. Między $14-16$ r. ż. u. Dz., a nieco później u Ch. przypada okres autoanalizy i pisania pamiętników, zastanawiania się nad sensem życia w ogóle, a nad sensem własnego życia w szczególności, spostrzeżenia swojej odrębności, chwilami nawet gwałtowne jej podkreślanie. To wszystko krystalizuje nową świadomość czy lepiej mówiąc, samoświadomość jednostki.

Młody człowiek wymaga w tym czasie przyjacielskiego zainteresowania się nim, dyskutowania $\mathrm{z}$ nim na tzw. życiowe tematy, czytania fachowej literatury psychologicznej. Chętnie też skorzysta z pomocy testu projekcyjnego (Hector, Szondi itp.), albowiem młodemu narzuca się mnóstwo pytań. Na wiele $\mathrm{z}$ nich sam nie bardzo potrafi sobie odpowiedzieć. Chociaż jest on niekiedy nieco arogancki, to jednak jest to najczęściej tylko maska, pod którą kryje się niepewność, jak myśleć, co sądzić, jak postąpić, co wybrać, co uznać za słuszne, jak pogodzić przeszłość z teraźniejszością itp.

Młody na różne sposoby broni swego nowo odkrytego „ja”, stosując szereg mechanizmów obronnych. Weldług psychoanalizy, wiszelkie mechanizmy obronne mają swe „miejsce” w warstwie podświadomej „,ja”.

${ }^{29} \mathrm{~K}$. Dąbrowski, O dezintegracji pozytywnej, Warszawa 1964, s. 46-47.

30 Wł. Prężyna, ks., Kształtowanie się życia religijnego w świetle psychologii rozwojowej, w: Znak, n. 210, 1971, 1575.

31 Tenże, s. 1575 n. 
Młodzi, posługując się nimi (np. racjonalizacją, kompensacją, projekcją, identyfikacją, reakcją upozorowaną) czynią to zwykle nieświadomie ${ }^{32}$. W tym też świetle należy patrzeć na ich samoocenę, na wysuwane trudności czy zarzuty.

\section{b) Kłopoty światopoglądowo-religijne}

Lata rozwojowe 14/15-18/19, mające swoją fazę przygotowawczą na przełomie $11 / 12$ r. $\dot{z}$. , cechują charakterystyczne przemiany, nie tylko fizyczne, ale i psychiczn e. Przemiany te znajdują swój wyraz szczególnie w zakresie odbioru treści, pochodzących z zewnątrz, bądź tėż wewnętrznych, wcześniej zawłaszczonych. Ogólnie rzecz biorąc, przemiany te polegają na przesunięciu akcentu z akceptacji bardziej emocjonalnej (dominującej w okresie dzieciństwa), ku a kceptacji bardziej rozumowej (odgrywającej stopniowo rolę wiodącej w okresie dorastania) ${ }^{33}$.

$\mathrm{Na}$ wspomnianą wyżej przemianę wpływają określone uwarunkowania wewnętrzne dojrzewającej psychiki młodzieńczej, które w tym czasie podlegają funkcjonalnym przesunięciom i przeobrażeniom. Specjalistyczne badania dowiodły ${ }^{34}$, że we wspomnianym okresie rozwojowym nasilają się przeobrażenia w sferze umysłowej, powodujące z kolei dominację akceptacji rozumowej nad emocjonalną w procesach poznawczych, konstytuujących u młodzieży dorastającej osobiste przekonania religijne.

Warto zapoznać się bliżej z owymi uwarunkowaniami wewnętrznymi, oddziałującymi w sposób c zynny na tworzenie się przekonań religijnych u dorastających. Spróbujemy je tutaj wyliczyć:

- Dążenie do syntezy na u kowej, czyli poszukiwanie jakiejś wizji całościowej i wewnętrznie koherentnej tych prawd religijnych, które młodzież poznała na katechizacji.

- Bardzo żywo odczuwana potrzeba argumentacji rozumowej w celu uformowania sobie przekonań religijnych, opartych nie na samym autorytecie dorosłych, ale na własnych przemyśleniach argumentacji ,za" i ,przeciw”.

- Nowe ustosunkowanie się do poznanych wcześniej prawd religijnych wynika $\mathrm{z}$ osiągniętej w międzyczasie przez dorastającego wie dzy ogólnej i religijnej.

32 Por. Zenomena Plużek, Wpływ podświadomości na życie świadome, w: Znak, n. 210,1971 , s. $1596-1603$.

${ }_{33}$ Por. Henryk Piszkalski, ks., Rola uwarunkowań wewnętrznych $w$ ksztattowaniu się przekonań religijnych $u$ młodzieży $w$ okresie dorastania. Studium psychologiczne. Kraków, Papieski Wydział Teologiczny, 1973, s. 283 (praca doktorska $\mathrm{w}$ maszynopisie).

34 Tenże, s. $283-284$. 
- Na inne spostrzeżenie młodego na prawdy religijne wpływa rozwinięta świadomość odnośnie własnej a u tonomi i os obow ości owej. Skłania ona młodego do podejmowania inicjatywy w formowaniu osobistych przekonań religijnych.

- Poczucie swej odrębności psychicznej jest u dojrzewającego źródłem podkreślenia swego prawa do organizowania osobistego życia religijnego i moralnego.

- Postęp w latach i doświadczeniu życiowym każe młodemu inaczej, tj. w sposób bardziej dojrzały patrzeć na poznane prawdy religijne: „Byłem za młody — pisze respondent — aby pojąć sens podawanej prawdy religijnej".

- Zaostrzenie zmysłu krytycyzmu pozwala w okresie dojrzewania ustosunkować się do prawd religijnych $\mathrm{z}$ odpowiednim dystansem poznawczym i usunąć wszystko, co w jego wierzeniu było legendą: „Prawdą jest to, co sam odkryję, o czym się sam przekonam” ${ }^{35}$. wyznaje młody człowiek.

- W ramach młodzieńczego idealizmu teoretycznego oraz krytycznego ustosunkowania się do prawd wiary młody stara się tworzyć nowe wizje świata, dającego się pogodzić z zasadami religijnymi. Stąd, jego skłonność do aktywności r eformatorsko-doktrynerskiej.

- Charakterystyczny dla młodego w tym okresie pęd odkrywczy pcha go do częstych z mian zainteresow ań.

Prawdy religijne mogą paść nieraz ofiarą tegoż pędu. Powyższe uwarunkowania psychiczne, czyli wewnętrzne wpływają na dojrzewającego tak dalece, że niekiedy rozstaje się on z pewnymi prawdami czasowo lub nawet na stałe. Mniej i krócej się modli. Rzadziej uczęszcza do sakramentów św. Niechętnie się afiszuje z praktykami religijnymi. Religijność jego jednak się interioryzuje.

Dojrzewający jest również bardzo wrażliwy e mo c jo n a ln i e. Niektórzy psychologowie skłonni są nawet mówić - analogicznie do wie$\mathrm{ku}$ umysłowego - o wiek u u c z u c i ow y ${ }^{36}$. Młody, jeszcze bardziej, aniżeli dziecko, pamięta przykrości doznane w związku z praktykami religijnymi, np. od rodziców czy księdza. Poza tym, dojrzewający przeżywa charakterystyczne stany uczuciowe w sposób skrajny, od zapamiętałego zapału do prostracji duchowej. Stąd też, młody wymaga zawsze szczególnej cierpliwości i odczekania aż fala podniecenia emoejonalnego nieco opadnie.

Dojrzewający jest także, bardziej niż dorośli, niesystematyczny w pra-

${ }^{35}$ Mieczysław Maliński, To nie takie proste, mój drogi, w: Znak, Kraków 1972 , s. 8.

${ }_{36}$ Por. M. Żebrowska, Psychologia rozwojowa dzieci i mtodzieży, wyd. PWN Warszawa 1977 , s. 720. 
cy nad sobą, cierpiąc często na niedostateczny imperatyw woli. Stąd, praktyki religijne, wymagające systematyczności, jak np. codzienna modlitwa, częstsza spowiedź i Komunia św., niedzielna Msza św. itp. ulegają niekiedy zaniedbaniu. Należy jednak zauważyć, że owe zaniedbaniia w praktykach religijnych, są częstsze, aniżeli bunt przeciwko dogmatom, częstsze jest rozmijanie się z chrześcijańską etyką, aniżeli z prawdami objawionymi.

\section{c) Wartości a zachowanie seksualne (trudności moralne)}

Należy na wstępie zrobić ważną uwagę. W niniejszym problemie trzeba odróżnić o braz o bi e g o w y (popularny) zachowania seksualnego młodzieży oraz o b a z na k k w y. Rozróżnienie to jest — naszym zdaniem - bardzo istotne dla oceny zagadnienia.

Na pierwszy rzut oka wydaje się że młodzież współczesna jest bardziej rozpasana seksualnie, niż dawniejsza. Na dowód tego wskazuje się na takie zjawiska, jak: wczesna inicjacja seksualna, wzrost liczby stosunków przedmałżeńskich, ciąż w okresie dorastania itp. Na pewno takie wypadki - nawet dość liczne - stwierdza się w dobie obecnej. Łatwo jednak o generalizację, czego należy unikać.

Na u k owe badani a, które przeprowadził jeszcze w roku 1967 D. Offer (USA) ${ }^{37}$ i Schonfield $\left(1965\right.$ - Londyn) ${ }^{38}$, nie potwierdzają takiej tezy.

D. Offer badał przez 3 lata Ch. w środkowych klasach szkoły średniej. Okazało się, że tylko 5\% Ch. miało już stosunki seks., ale 80\% badanych wyznało, iż aprobuje przedmałżeńskie stosunki dopiero po szkole średniej.

M. Schonfield w grupie Ch. i Dz. w wieku 15-19 lat, liczącej ponad 1800 osób, wybranych z kilku dzielnic Londynu spośród różnych warstw społecznych, stwierdził, że tzw. wybujały erotyzm młodzieży jest wytworem fantazji ${ }^{39}$.

Spośród młodszej grupy w wieku 15-17 lat tylko $11 \% \mathrm{Ch}$. i $6 \% \mathrm{Dz}$. miało stosunki seksualne. W grupie starszej $17-19$ r. ż. procenty wzrosły do $30 \%$ u Ch. a $16 \%$ u Dz. A zatem, $4 / 5$ Ch. i prawie $9 / 10 \mathrm{Dz}$. z badanej grupy nie miało stosunków seksualnych.

U nas w kraju - według niedawnych badań - też nie jest tak groźnie ${ }^{40}$. Zdaniem autorów (K. Imieliński, A. Janczewski, B. Popielski) ob-

37 D. Offer, Normal adolescent: Interview strategy and selected results, w: Archives of General Psychiatry, 17: 285-290, 1967.

${ }_{38}$ M. Schofield, The Sexual Behaviour of Young People, Boston: Little, Brown $1965,29-31$.

39 Tenże, s. 30 .

40 Por. u nas w kraju: K. Imieliński, Postęp $w$ uświadomieniu płciowym mło- 
niża się wprawdzie wiek inicjacji seksualnej, ale wciąż są to jeszcze wypadki raczej wąskiego ima r g i nes u społecznego, który zawsze był notowany i nie jest czymś zgoła nowym. Toteż, nie wolno, tego marginesu, ani poszerzać, ani notowanych przypadków generalizować. Mamy tutaj bowiem, do czynienia z młodzieżą zaniedbaną, pochodzącą często z małżeństw rozbitych. Trzon młodzieży jest zdrowy. Chodzi tu raczej o znany problem niekonsekwencji u młodych między poznaną prawdą (wartością) a życiem (czyn etyczny). Według W. Grühna pochodzi to stąd, że „poznanie wartości rozwija się szybciej, niż zdolność do czynu etycznego i religijnego" ${ }^{41}$.

\section{d) Wrastanie w społeczeństwo}

Oprócz dojrzewania umysłowego, emocjonalnego i wolitywnego, dorastający przeżywa także dojrzewanie s p ołe c z n e. Polega ono na rozluźnieniu więzów, łączących go $\mathrm{z}$ własną rodziną i stopniowe przejmowanie bardziej samodzielnych i odpowiedzialnych obowiązków w grupach społecznych. Proces ten dokonuje sę w tym samym przedziale czasowym, co dojrzewanie psychiczne, tj. od 11/12 r. ż., a nasila się po 18/19 roku życia. Wzrastanie $w$ społeczeństwo zazwyczaj nie obywa się bez pewnych konfliktów z otoczeniem: z rodzicami, nauczycielami, stróżami porządku publicznego i w ogóle ze światem dorosłych.

Psychologowie zauważają że kryzys zaufania do rodziców i starszych przechodzi e wolucję: Zaczyna się ok. 12 r. ż., dochodzi do szczytu w wieku 15-16 lat a następnie słabnie.

Prowadzone $u$ nas $w$ kraju przez J. Skorupską badania ${ }^{42} \mathrm{w}$ warszawskich szkołach średnich wykazały, że wśród 300 osób tylko 19,7\% młodzieży wyznało, że ich współżycie z rodzicami jest pozytywne. Cała reszta, a więc $80,3 \%$ skarżyła się na stosunki negatywne $z$ rodzicami swoimi.

Młodzi, rozluźniając swoje więzi z rodzicami, wchodzą równocześnie w nowe grupy ró wieśnicze, ,paczki”, organizacje młodzieżowe (sportowe, kulturalne itp.). Mamy zatem, do czynienia tutaj ze stadiem pośrednim między dzieciństwem a dorosłością, czyli z wrośnięciem w społeczeństwo.

W tym miejscu warto jeszcze wskazać na przyczyny powstawania

dziė̇y (wyniki badania ankietowego). w: Psychologia wychowawcza 1961, n. 2; A. Janczewski, Erotyzm dzieci $i$ młodzieży, wyd. 2, Warszawa 1973; B. Popielski, Zaburzenia płciowe w wieku dorastania, Warszawa 1957. s. 208.

41 W. Grühn, Religijność wspótczesnego człowieka, wyd. Pax, Warszawa 1966,

${ }_{42}$ J. Skorupska, Dlaczego jest nam z wami źle? w: Wychawanie 1961, n. 5; Konflikty miodzieży dorastajacej $z$ osobami dorostymi, w: Psychologia wychowawcza 1958, n. 2. 
konfliktów między dorastającymi a ich rodzicami. Odwołamy się ponownie do wspomnianych już wyżej badań J. Skorupskiej. Czynnikami, rodzącymi konflikty między młodzieżą a dorosłymi są w tym okresie:

1) Cechy oso,bowości dorosłych: konserwatywny sposób myślenia, przywiązanie do staromodnych konwenansów, przebrzmiałe przekonania moralne, religijne, estetyczne, kulturalne itp. - 97\% Dz. $-86 \% \mathrm{Ch}$.

2) Nadmierne ograniczanie swobody: $85 \%$ Dz. - 53\% Ch.

3) Niewłaściwe metody wychowawcze: $54 \%$ Dz. - 58\% Ch.

Dorośli wskazują na następujące braki młodzieży: nieposłuszeństwo, upór, złe wyniki w náuce, śmiałość w wygłaszaniu poglądów itp.

Na powstawanie konfliktów między młodzieżą a pokoleniem dorosłych wpływają $\mathrm{m}$. in. zmienione warunki ekonomiczno-społeczne, np. praca kobiety, system stypendiów uniezależniających młodych od rodziców, praca poza własnym środowiskiem, system ubezpieczeń, niwelujący zobowiązania dzieci wobec rodziców, przejście z kultury rolniczo-miejskiej do kultury miejsko-przemysłowej, wzrastanie młodzieży w świadomości, że przyszłość do niej należy, że społeczeństwo ma obowiązek zapewnienia jej należytej opieki itp.

Starsze pokolenie może konflikty w okresie kryzysu dojrzewania złagodzić przez równomierne rozkładanie pewnych obowiązków między siebie i młodych od wczesnych lat ich życia. To rozwinie $w$ nich także poczucie odpowiedzialności za powierzane im obowiązki. Jakże słuszna jest jednak uwaga T. Kotarbińskiego: „Trzeba umieć utrzymać więź uczuciową, nawet gdy młoda istota wchodzi w wiek przekory. I nie ustępować, ilekroć wypadnie czegoś wymagać lub na coś nie pozwalać" (Z Medytacji o życiu godziwym).

\section{DIE REINFUNGSKRISE ALS EIN PSYCHOLOGISCHES PROBLEM}

Zusammenfassung

Die s.g. Reifungskrise in der Pubertät stellt mehrere Fragen an den Psychologe. Sie sind auch heute nicht leicht zu beantworten. In diesem Artikel werden, nicht nur terminologische und meritorische Probleme geklärt, sondern auch eine Stellungnahme den falschen Ansichten von einigen Reifungserscheinungen bei der heutigen Jugend beobachteten gegenüber, vorgenommen. Die Kritik stützt sich auf die neuen Untersuchungen amerikanischer, englischer und polnischer Authoren. Nach Erläuterung einiger Termin-Probleme werden verschiedene Richtungen des Reifungsprozesses dargestellt, wobei die Komplizierung der Reifungserscheinungen und der mitwirkenden Bedingungen nich zuletzt aufgrund eigener Untersuchungen des Authors an Licht gebracht sind.

Die Reifungskrise ist aber nicht nur ein Problem für die Psychologen, für die Eltern und Erzieher, sondern auch für den Reifenden Jugendlichen selber. Es kom- 
men hier solche Reifungserscheinungen in Frage, wie: Das neue Auftauchen des Ich-Bewusstseins, die Umwandlung im Bereich der Intellektuellen-, Emotionellen-, und Willensvorgängen, bezüglich der neuen weltanschaulichen und religiösen Erfahrungen, und nicht zuletzt die ganz neue Schwierigkeiten mit dem Eros und Sex, die aber im Lichte der wissenschaftlichen Sondierungen nicht allzutragisch genommen sein dürften. Die letzten Krisenerscheinungen sind mit der Eingliederung in die Gesellschaft der verantwortlichen Erwachsenen verbunden.

Die moderne Psychologie sucht dem Jugendlichen in der Phase seiner Reifungskrise mit ihrer eigenartigen Hilfe entgegenzukommen. 